\title{
Petitions and the Social Context of Political Mobilization in the Revolution of $1848 / 49$ : A Microhistorical Actor-Centred Network Analysis
}

\author{
Carola LipP AND LOTHAR KREMPEL
}

A great part of the political movement in the Revolution of I 848 took place in the form of group and mass petitions. The National Assembly in Frankfurt, the first national German parliament, received I 7,000 petitions from more than three million people. ${ }^{\mathrm{A}} \mathrm{A}$ great number of petitions, analysed by German scholars such as Best, dealt with the question of a liberal market economy, with problems resulting out of the developing process of industrialization, and with protective duties. The petitions expressed different group interests, articulated by craftsmen, merchants, entrepreneurs, and workers, who responded to current economic and social restraints. Another complex of petitions formulated requests regarding the constitution, the liberalization of the political system, or the organization of education, especially the separation of church and state. Another large mass of revolutionary petitions was addressed to the rulers or the ruling bodies of the different German states and was concerned with regional conflicts, and the adoption of ideas that were developed at national level.

Until now, these petitions have been analysed as the product of a collective body, and the signatories of these petitions have been identified through the names of the groups that were given at the head of the petitions. The assumption was that the information and social selfdefinition of the titles represented the actual social groups that issued these petitions. Due to the informational poverty of the sources, which usually only contained a handwritten name, surname, and locality, researchers were not able to reconstruct the social and cultural context of the petitioners. These petition lists mention occupations in only a few cases. Therefore, a differential social analysis was almost impossible, and it was taken for granted that there was a similarity between the named authorship and the social status of the signatories. A closer inspection of one of these

I. Heinrich Best, Interessenpolitik und nationale Integration I848/49. Handelspolitische Konflikte im frübindustriellen Deutschland (Göttingen, 1980), p. I27; Joachim Heinrich Kumpf, Petitionsrecht und öffentliche Meinung im Entstehungsprozeß der Paulskirchenverfassung I 848/ 49 (Frankfurt [etc.], I983). 
petitions reveals an astonishing configuration. A petition, headed Gewerbeleute von Esslingen (businessmen from Esslingen), that asked for protective duties for industrial textile products, was actually organized by the local entrepreneurs who signed at the top of the lists. But the identification of the other signatures shows that two-thirds of them were not from merchants but from workers, and an even narrower analysis makes clear that the petition must have been circulating in various production areas of the local industrial plants. Such a different perspective can only be made if the analysis is based on an identification of the historical actors.

In the case presented here, we have made a computer-based reconstitution of the entire population of the city of Esslingen, one of the rising industrial towns in the kingdom of Württemberg, with about I3,000 inhabitants in $1849 .{ }^{2}$ The reconstitution is built on the individual social identification of each actor through the linkage of more than i so sources. ${ }^{3}$ With three textile firms and a plant for the production of railway engines and carriages, this middle-sized town was one of the most progressive industrial centres in Württemberg at that time. In I 850 , we find that nearly 20 per cent of the household heads in the town were industrial workers. With 38 per cent of all household heads, craftsmen still represented the majority of the inhabitants. Although Esslingen became a Württembergian administration centre during the pre-Revolutionary period, known as the Vormärz, the town still lived on its past as a free Reichsstadt and contained within its community boundaries about Io to I 2 per cent agriculturallybased households, most of them small vintagers producing wine for the regional market. In its social spectrum Esslingen represented the typical mixture for the German southwest, a region with partible inheritance and small landholders, who were forced to take up artisanal or industrial occupations to supplement the income of the family.

The following analysis presents an exemplary microhistorical case study of the petition movement in Esslingen, and shows the political, social, and cultural networks in which the petition movement in this politically very active town was embedded. Eleven petitions ${ }^{4}$ were analysed, which had

2. The project, financed by the Deutsche Forschungsgemeinschaft, is led by Professor Carola Lipp. Her assistant is Dr Jürgen Nemitz at the University of Göttingen. The network analysis was made by Dr Lothar Krempel and Michael Schnegg, Cologne.

3. To identify people socially the most important sources were inhabitant, tax and voting lists, town militia and civic guard registers, church registers, house assessment lists, and sources that linked the people to their actual workplace. On the political level, the records are based on the name lists of petitions, membership lists of associations, committees and communal institutions. 4. Addressee of five petitions: the Württembergian government and King; addressee of six petitions: The National Assembly in Frankfurt. The population of Esslingen wrote far more petitions but not all of the sources contained lists of names. 
added name lists of different lengths. 5 Table I overleaf shows the issues that were formulated. Petitions were a form of political action which entailed low costs and normally few risks. The threshold of participation was rather low, but very often the signing of a petition marked the first step into political activity. Especially for people who felt marginalized, or were not prepared for long-term political involvement, petitions were an easy form of expressing their opinions and placing themselves in the realm of politics. As a quick way to mobilize the masses, petitions therefore were some of the most forceful, but often underrated, forms of revolutionary practice.

For historical research, the important aspect of petitions is that they represented actions in structured situations. Petitions during the Revolution were usually based on individual interaction and social contact, and they relied on indigenous networks and cultural organizations which contributed to the mobilization. They were also based on a long-term process of consensus formation during the Vormärz, ${ }^{6}$ when most of the liberal ideologies and goals were formulated, the legitimation of the bureaucratic monarchical state was questioned, and nationalist ideas were developed. The discussions which took place in the pre-Revolutionary period produced a collective definition of the situation which led to activities.

Though Württemberg, since I8I9, had been one of the rare German constitutional states with a near-parliamentary system, there was a lot of criticism of monarchical constitutional prerogatives, aristocratic privileges, and the authoritarian structure of bureaucratic administration. A central grievance was the repression of civil rights. The liberal movement in Württemberg which expressed these grievances dated back to the early I 830 s, when the first liberal associations were founded. These associations were sometimes formed as cultural associations, such as musical and choral societies, which seemed to occupy themselves with entertainment, but actually formed a crypto-political framework for the modelling of political opinion. These early associations of the Vormärz were the core of the organizations that developed during the Revolution: especially the main political parties, and, in Württemberg, the constitutionalist and democratic organizations. As the political "diagnosis" was clear, liberals in southwest Germany held large meetings, even before the Revolution started, to

5. The 3,744 identified signatures represent 2,159 persons for whom we mostly have more information regarding their social position, their profession and, in many cases, their further political involvement. But not all of them were integrated in the political life of Esslingen. Therefore our network analyses contain only I,986 petitioners that were linked to the organizational net.

6. Bert Klandermans, "The Formation and Mobilization of Consensus", in Bert Klandermans (ed.), From Structure to Action: Comparing Social Movements Research Across Cultures, International Social Movement Research, I (1988), pp. 174-196. 
Table I. Petitions with individual signatures in Esslingen I 848/49

\begin{tabular}{|c|c|c|c|c|c|}
\hline & Petition & Date & Signatures & Identified & $\%$ \\
\hline Phase 1( T1) & $\begin{array}{l}\text { Petition to the Conservative } \\
\text { Government and King of } \\
\text { Württemberg: demanding civil rights }\end{array}$ & 28.2.1848 & 104 & 104 & 100 \\
\hline \multirow[t]{6}{*}{ Phase 2 (T2) } & $\begin{array}{l}\text { Petition to the National Assembly: } \\
\text { Bruderbund, re Constitution }\end{array}$ & 29.5.1848 & 238 & 197 & 82.8 \\
\hline & $\begin{array}{l}\text { Petition to the National Assembly: } \\
\text { Catholics and religious freedom }\end{array}$ & 9.7 .1848 & 43 & 42 & 97.7 \\
\hline & $\begin{array}{l}\text { Petition to the National Assembly: } \\
\text { school-church relations }\end{array}$ & 12.8 .1848 & 232 & 232 & 100.0 \\
\hline & $\begin{array}{l}\text { Petition to the National Assembly: } \\
\text { artisanal requests }\end{array}$ & 4.12 .1848 & 245 & 244 & 99.6 \\
\hline & $\begin{array}{l}\text { Petition to the National Assembly: } \\
\text { businessmen }\end{array}$ & 20.12 .1848 & 248 & 241 & 97.6 \\
\hline & $\begin{array}{l}\text { Petition to the National Assembly: } \\
\text { duties on wine }\end{array}$ & 23.12 .1848 & 541 & 531 & 98.2 \\
\hline \multirow[t]{4}{*}{ Phase 3 (T3) } & $\begin{array}{l}\text { Petition to the Liberal Government of } \\
\text { Württemberg }\end{array}$ & 9.3 .1849 & 498 & 496 & 99.2 \\
\hline & $\begin{array}{l}\text { Petition to the King of Württemberg: } \\
\text { (National Constitution) }\end{array}$ & 22.4 .1849 & 1367 & 1233 & 90.2 \\
\hline & $\begin{array}{l}\text { Petition to the Württembergian Minister } \\
\text { of Justice: prisoners in Baden }\end{array}$ & 25.7.1849 & 68 & 68 & 100.0 \\
\hline & $\begin{array}{l}\text { Petition to the Württembergian Minister } \\
\text { of Foreign Affairs: prisoners }\end{array}$ & 30.8 .1849 & 358 & 356 & 99.4 \\
\hline Total & & & 3942 & 3744 & 95.0 \\
\hline
\end{tabular}


discuss their demands, i.e. to formulate prospective challenges that were part of the later requests articulated in petitions at the beginning of the Revolution. On this level, people discussed grievances, shaped their political positions and adopted goals that were represented by the liberal movement.

The character of political developments during the Vormärz structured our analytical approach, which combines actor-centred perspectives with the structural view of network analyses, and uses techniques of visualizations of social relations and structures. ${ }^{7}$ If political behaviour was embedded in the political culture and in the structure of everyday life of a city, there had to be a strong relationship between the organizational culture of the Vormärz and the political actions of people who were mobilized during the Revolution. Furthermore, we expect that political experiences during the Vormärz structured the forms of activities in I 848 . And, indeed, usually the same strategies and measures observed in preRevolutionary times were reproduced during the Revolution. What differed was the acceleration of action, and the process of social diffusion and mass mobilization, which had its special political impact on an already ideologically destabilized system.

Petitions were one of the established political instruments used in local politics. Therefore, we have analysed the relationship between the actions taken during the Vormärz and in the petitions of 1848 . We found that people who, (I) were active members in the local associations, (2) were used to petitioning, or (3) had electoral functions in the local community, were far more prone to participate in the Revolutionary movement than others (see Figure I overleaf).

This figure is based on membership data from more than twenty-five associations, the most important among them being the liberal Civil Society (Bürgergesellschaft) and several liberal choral societies founded between I 827 and I 847 . As the most important cultural organizations in the town, these are one of the centres in our network analyses (see Figure 2).

We also looked at nine committees that organized local charities or local celebrations, and which played an important role in the configuration of the local elite. Next to the associations, a central function in the process of political formation in the Vormärz was performed by the local citizen initiatives. These activities (twenty-two analysed) usually consisted of

7. These techniques are based on force-directed placement algorithms, which can be extended to handle valued graphs and even two-mode data. Compared to the classical statistical approach which reduces information and eliminates small phenomena, these methods allow a reconstruction of the overall structure from relational information, while preserving information on how single elements are tied into the network. See Lothar Krempel, "Visualizing Networks with Spring Embedders: Two-mode and Valued Data", in American Statistical Association (ed.), Proceedings of the Section of Statistical Graphics (Alexandria, VA, 1999), pp. 36-45. 


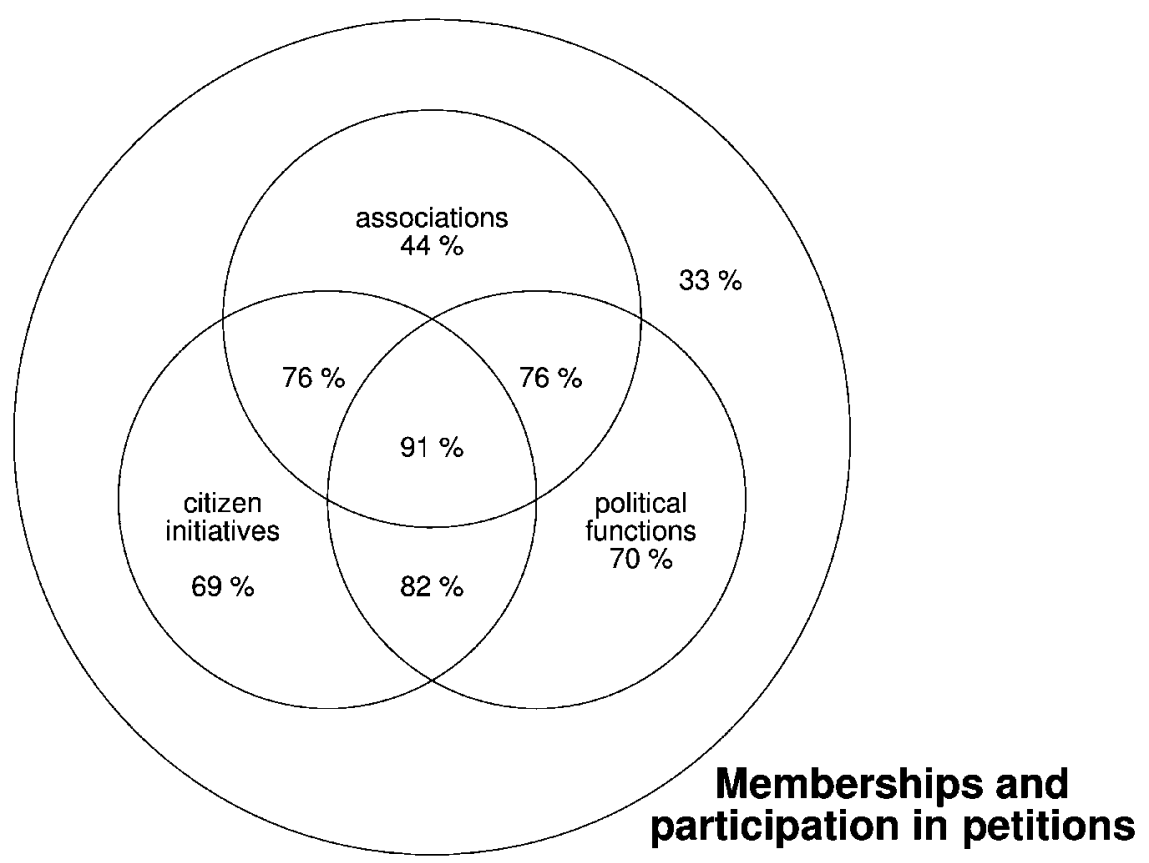

Figure I. Participation in petitions and overlapping memberships

The highest participation rate (9I per cent) is found for those individuals who were connected to all three types of membership; 33 per cent of petitioners did not have any links to the organizational structure; 69 per cent of the actors who had links with citizen initiatives participated in the petition movement, while only 44 per cent of the members of associations signed petitions $(\mathrm{N}=5103$ male inhabitants of Esslingen).

petitions and were in some aspects models for later activities. The citizen initiatives which were analysed (called Bürgerinitiativen = BI) were normally concerned with neighbourhood problems or criticism of measures of the city executive. A fourth aspect of political activity that was important for political life in Esslingen was the membership of political institutions, such as the community council or citizens' committee. Other political functions included the secondary electors for the Württembergian parliament, titular offices in the local administration, and jurors. Finally, the members of political organizations that originated during the Revolution constituted another important group, integrated into the social network. With the foundation of these groups the network became polarized between the national and constitutional liberals on the one hand and the developing Democratic Party, that challenged the constitutional monarchy, on the other. These two organizations contributed to the leftright axis of the network, along which most of the events were organized. 


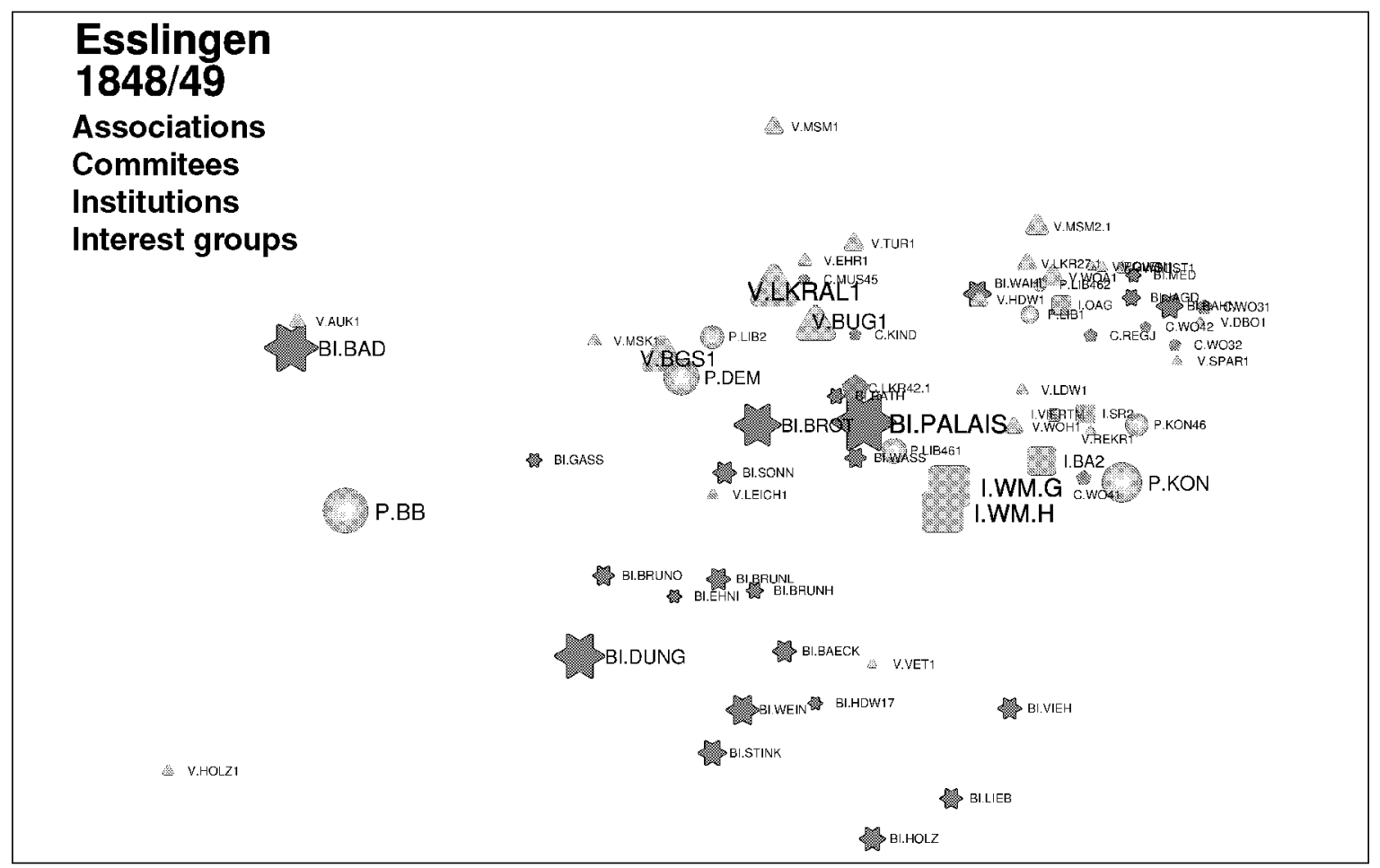

Figure 2. The landscape of activities in Esslingen

Political formations are marked with spheres and identify a left-right dimension in the layout: the Bruderbund (P.BB) on the left, the Democrats (P.DEM) in the middle and two constitutionalist factions at the right (P.KON), with several smaller liberal activities in between the latter two. Associations are marked as triangles, institutional memberships with squares and committees with pentacles. Citizen initiatives are shown as stars. 
All groups had overlapping memberships, and some inhabitants of Esslingen were members of five to seven associations and took part in more than five local initiatives.

The network that was created through these multiple relations was rather complex and included more than ninety activities (see Figure 2). The large or small nodes in Figure 2 represent the size of the groups and the distances between the nodes reflect the degree of overlapping memberships. Organizations or groups that lie very closely together shared a great number of common participants. As a methodological constraint, the visualized networks contain only people who signed petitions and were involved in a second form of activity during the Vormärz or in the Revolution. The visualized network does not include people who were not integrated into the existing social structure of organizations and relations defined by the above mentioned groups. Among 5,097 male inhabitants of Esslingen older than I 4 years of age in I 848 , there were 2, I 84 signatories of petitions, but only I, 284 were identified as part of the cultural substructure, i.e. took part in one of the above-mentioned activities. This leaves 900 people who were obviously mobilized by the issues raised by the petition movement. On the other hand, there was a group of 702 persons who were members of different social organizations but did not sign a petition.

To observe the diffusion and acceleration of the mobilization process, we have structured the petition movement in three historical phases. The first phase is defined by the eve and the first days of the Revolutionary movement in February 1848 and two years before. It includes political factions of an election campaign of 1846 and the signatories of the first petition to the Württembergian sovereign, demanding basic civil liberties which were granted by the King in March I 848. This petition was primarily carried out by people who had already been engaged in former political activities during the election campaign of $\mathrm{I} 847$, which had divided the entire population of Esslingen into two political camps. ${ }^{8}$ The second phase was characterized by petitions addressed to the National Assembly in Frankfurt, elected in the national elections of May i 848 . Until December I 848, when the new constitution was discussed, the people of Esslingen, like inhabitants of other towns in Germany, sent many petitions to different parliamentary commissions in Frankfurt.

The third phase of the petition movement in I 849 related to the internal affairs of Württemberg, the stabilization of the liberal government elected

8. For historical details please see Carola Lipp, "Zum Zusammenhang von lokaler Politik, Vereinswesen und Petitionsbewegung in der Revolution 1848 . Eine Mikrostudie zu politischen Netzwerken und Formen der Massenmobilisierung in der politischen Kultur der Revolutionsjahre”, Esslinger Studien, 36 (1997), pp. 2 I I-269. 


\section{Petition activity over time}

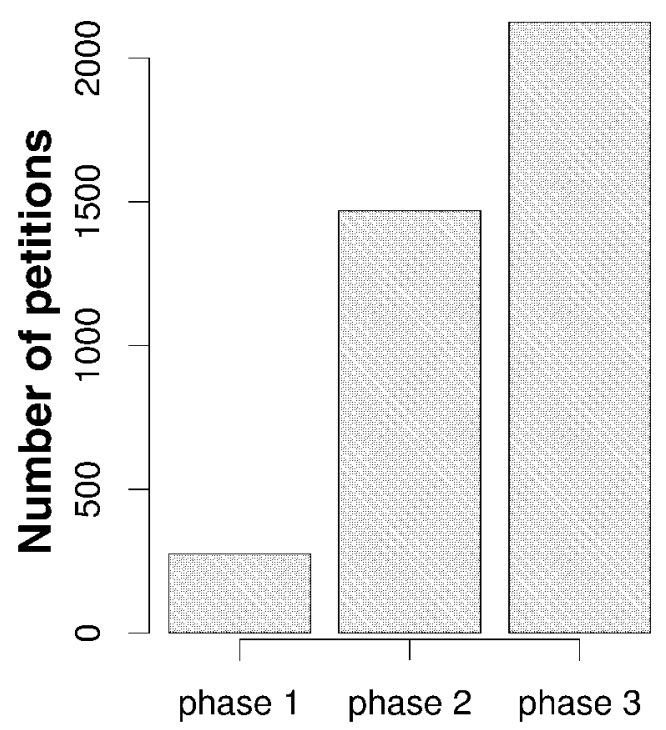

Figure 3. Historical phases of the petition movement

in March and the question of whether the King of Württemberg would accept the constitution written in Frankfurt. The Prussian King had already rejected a national constitution and the imperial crown offered by the Frankfurt parliament in March I 849. In Württemberg, the petitioners were more successful and, under pressure from the large petition movement, the Württembergian King accepted the Reichsverfassung and the provisional government in April I 849 .

In this last phase of the German National Revolution more than half of the city's adult males were involved in the petition movement. Only a small group took part in all three phases; most of the people who left the petition movement at an earlier stage were intellectuals and state employees; others entered the movement in the second or even in the third phase.

When the Prussian army marched against Frankfurt in June I 849, the National Assembly fled to Württemberg, but was soon dissolved by the liberal government there which feared a war against Prussia. The last battles for the national constitution were fought by volunteers in Baden in June I 849 . Therefore the petitions signed by the Esslinger inhabitants in July I 849 concerned the fate of local volunteers who went to Baden and took part in the military campaign for the national constitution.

The central questions of our analyses were: how was the disposition to 
sign petitions related to other forms of political involvement; who participated at what stage; how did the political consensus spread, and did it reach people who were marginal in the field of pre-Revolutionary politics of the Vormärz, or had little experience of petitioning? As our analysis focuses on the impact of network structures based on the abovementioned membership in associations, institutions, and other groups, it concentrates on the core of people who participated in both types of actions. Opinion usually spreads through social contacts. The network structures resulting from the differing overlapping memberships should be an important indication of the diffusion of ideas and political initiatives. The exposure model we use in this study postulates that the disposition of an individual to engage in collective action is as great as the proportion of people who were already active in the person's environment. Depending on the place where an actor is positioned in the network of preRevolutionary activity, his multiplicative effect in the process of mobilization might be stronger or weaker and the actor himself might experience a drastic growth of activity in his personal life.

One would certainly expect a great intensity of contact among those people who were most active within the social and cultural life of Esslingen constituted by the different organizations, institutions, and cultural activities described above. Those who were not part of this structure seemed to be less likely to have a high degree of contacts and exposure to other people's opinions. Though this argument holds true in general, limited activity does not necessarily imply a low degree of contact. Consider the following case: an actor participates in only one event, but this event contains a large number of activists. The result will be a high degree of contacts. In other words: a high degree of participation is not a necessary condition for a high number of contacts.

The reasoning behind this argument is summarized in Figure 4, which differentiates between activists ( $\mathrm{A}_{\mathrm{I}}$ to $\mathrm{A} 8$ ) who had already become actively involved in the petition movement. Through a set of social organizations, events, and institutions, these activists are linked to others. Event $\mathrm{E}_{4}$ includes, for example, five activists whereas in the others only one or two activists of the petition movement are included. P marks people who were linked to certain groups within the structure but had not yet become active. There are great differences among these people: $\mathrm{P}_{5}$ is a member of one group, but has more contacts through his participation in $\mathrm{E}_{4}$ than, for example, $\mathrm{P}_{2}$ who is member of two groups (EI, E2) which have a fewer number of activists. In this figure $\mathrm{P}_{4}$ has the highest number of contacts.

Figures 5, 6 and 7, on pages $162-164$, show the overall rise of contacts and how quickly the movement spread. There is an especially steep increase in the number of people who had many contacts.

Large circles mark the activities in Esslingen (compare Figure 2), while 


\section{Activists (A), Events (E) and Exposure of Contact for (P)}
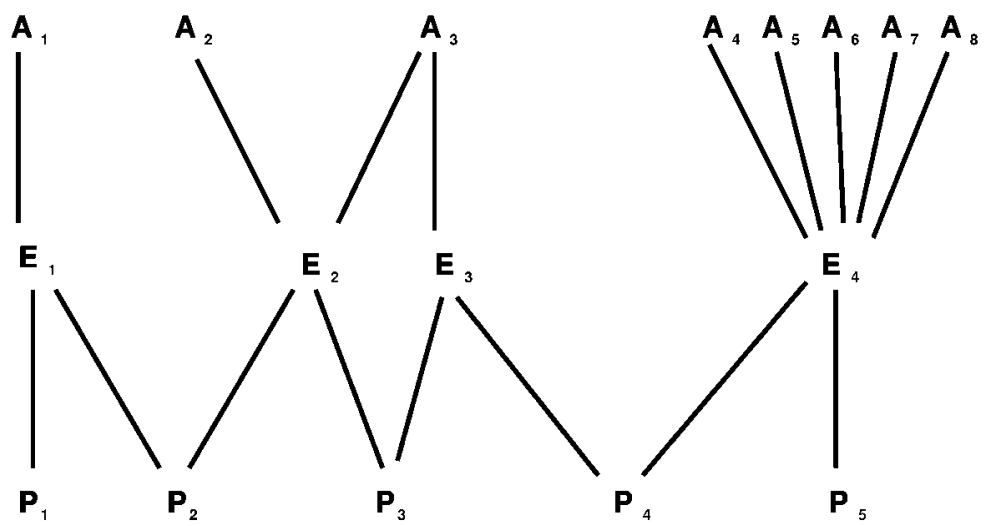

Resulting 1
exposure

3

3

6

5

Figure 4. Activists, groups/events and personal contacts

small circles symbolize single individuals. The individual levels of exposure are coded with a scheme of grey shadings, as can be read from the legend in the lower right. The mark-up of the background with convex hulls identifies the area in the landscape in which we find all actors of a corresponding level of exposure. The most outer hull (rendered as the lightest grey line) shows the area covered by the least exposed individuals (code I); the next, the area covered by the individuals exposed with the next level (code 2) etc. ${ }^{9}$

The analysis of the mobilization process can be described as a process of growing contact intensity between activists and inactive people. Contact intensity spreads with each phase of the petition movement. The distribution at the lower right bottom corner of each image and the different shades of grey and black show the degree of contact with other activists. Individual actors in the structure are shaded in accordance with the number of contacts made.

The mobilization process at the beginning of the Revolution started

9. A more refined graphic representation of the process described can be obtained from the coloured graphics available on: http://www.journals.cambridge.org/abstract So02085900100028I. These files are available for subscribers to the International Review of Social History only. 


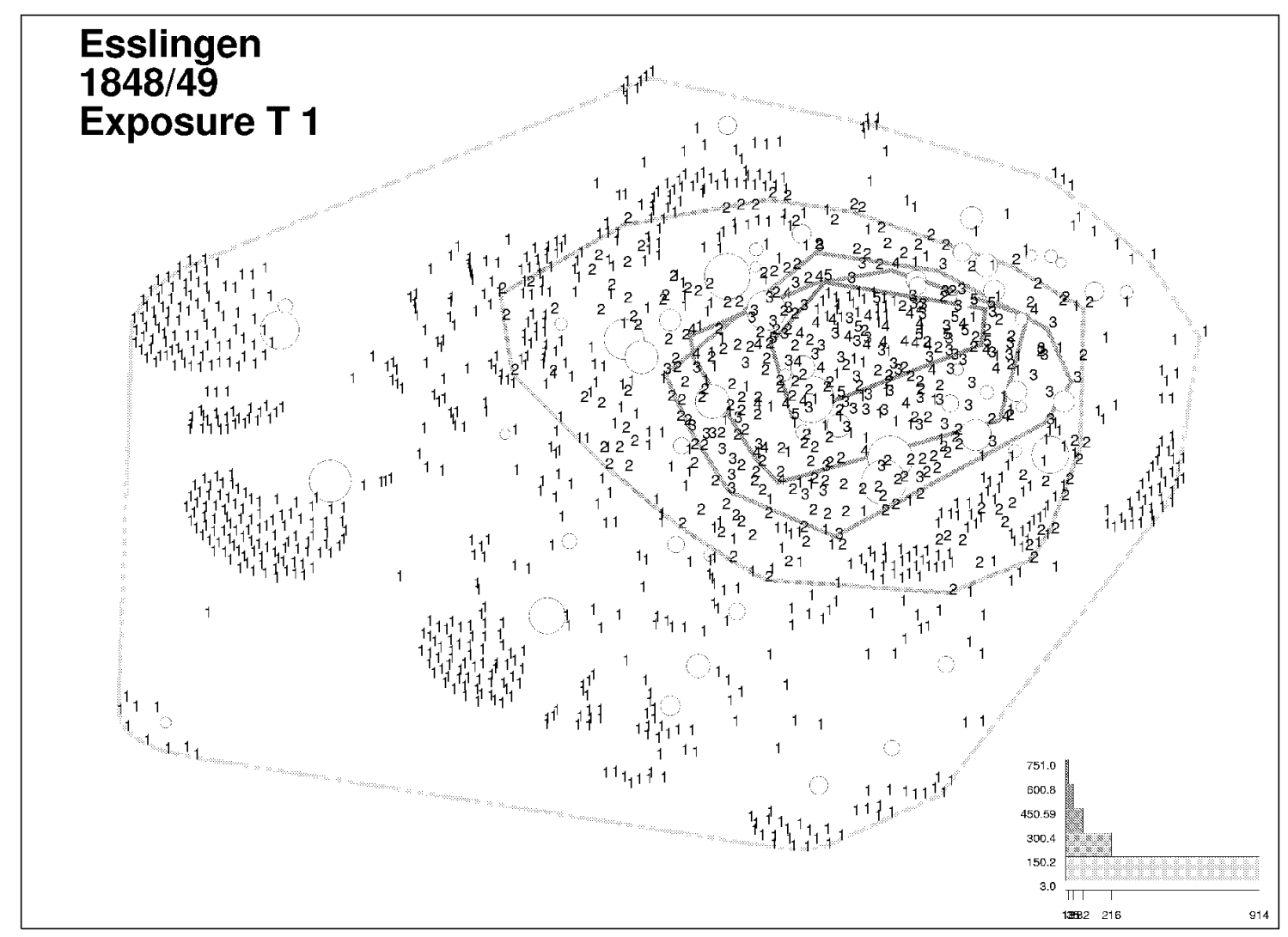




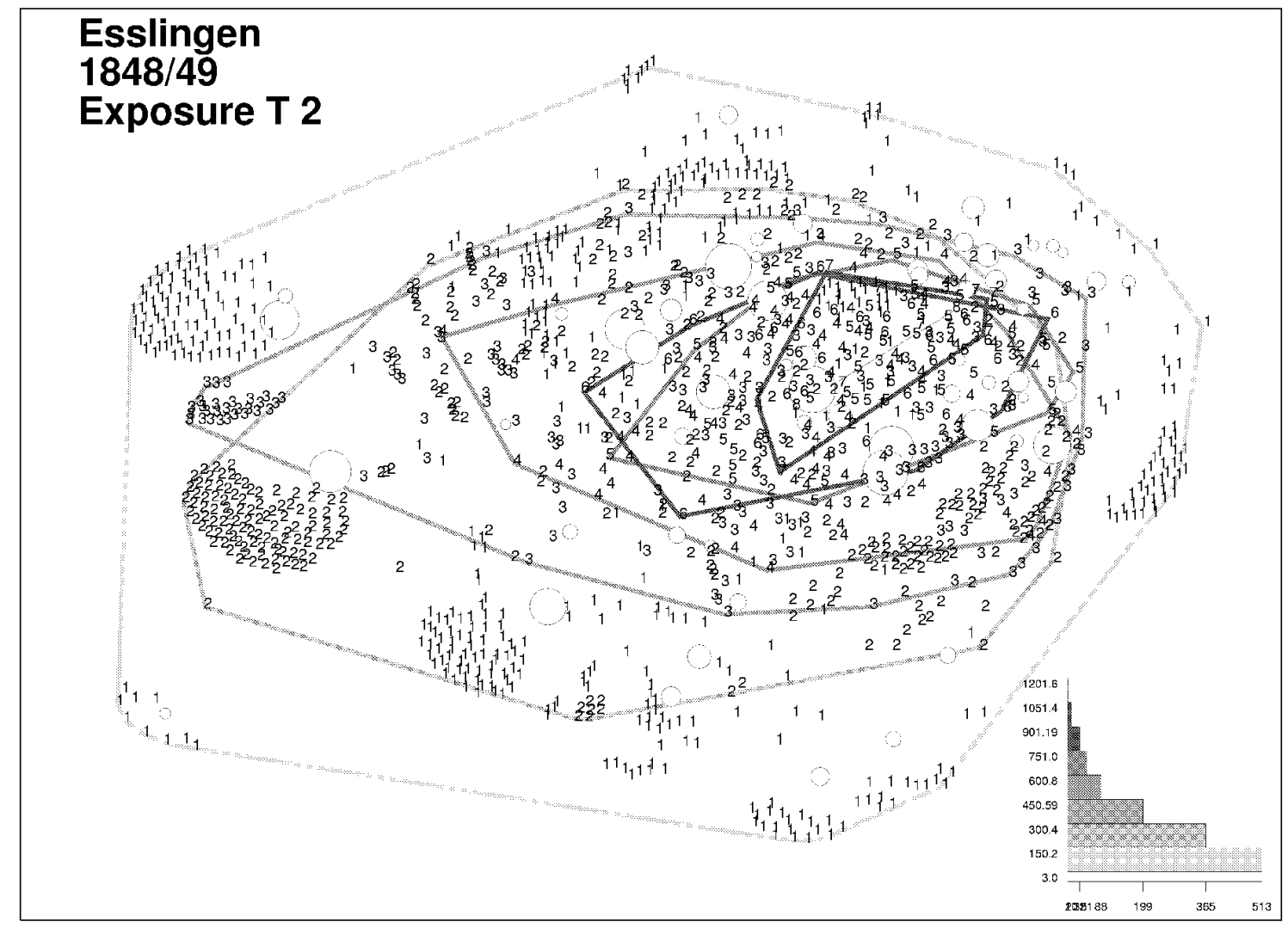




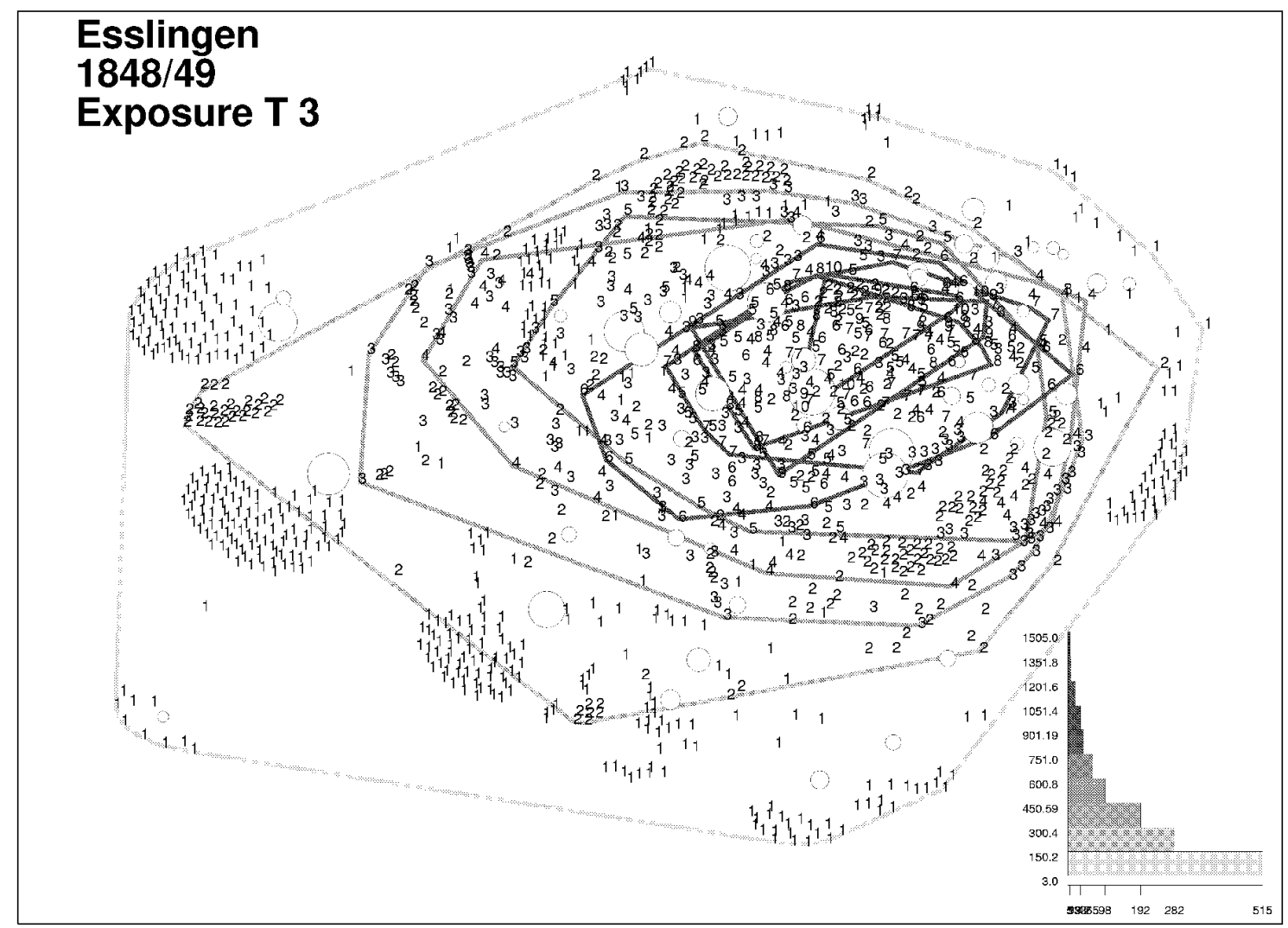

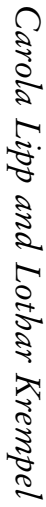


with a small number of people in the centre. Afterwards, in the second phase, contacts diffused rapidly from the centre of the social and cultural network structure to the periphery. The first phase is characterized by the activity of socially and politically highly integrated people, while in the second phase, the petition movement was joined by people who had far fewer contacts. How the intensity of contacts changed over the three periods becomes clear in Figures 5, 6 and 7. The images exhibit an overall rise of exposure and a steep increase of the spread for the most exposed actors. One can see the general tendency of the spreading of pressure from the centre of this system to its periphery.

A straightforward way to test the hypothesis of the relation between action and contacts is to correlate the degree of exposure/contacts with the degree of political action. The results show that there is a very high correlation of $\mathrm{r}=0.63$ for the first period of the movement. This correlation drops to $r=0.27$ in the second phase. In the third stage of the movement it rises slightly to $r=0.32$ because locally rooted people entered the movement. Most of the mobilization process therefore took place within the existing social and cultural substructure of city life.

This finding can be sustained if we look at the degree of political integration in the community. A strong indicator for local integration is represented by the right of citizenship, requiring, at that time, a household of one's own. For the citizen this right included the right to vote for the local council and the right to welfare support. Citizenship influenced the chances of people becoming members of the local political administration and electoral institutions. Noncitizens were not prevented from becoming members of free associations or neighbourhood activities. If we look at the three stages of the petition movement, it is not surprising that the number of people who have full citizens' rights in the town was highest in the first group (90 per cent) and lowest in the third group ( 57.6 per cent) thus indicating the different social positions in the town. The rate of people with citizenship was even lower among the 900 people who signed petitions and were not integrated in the organizational group structure shown in Figures 2, 5, 6, and 7.

The process of mobilization was strongly influenced by the social position of the participants. A statistical test of the relationship between the degree of enmeshment in the structure of social and political community life and the inclination to participate in the petition movement shows interesting differences between certain social groups. There is structured deviation from the general assumption that a high interrelation in the network structure leads to a high participation ratio. A comparison of the expected behaviour under the assumption of this model and the real level of participation reveals that the political behaviour of a group does not fit into the model in all cases. ${ }^{10}$ The residuals from the regression 
Table 2. Political behaviour of groups in Phase I

\begin{tabular}{lccc}
\hline Phase 1 & Intensity & Activity & Residuals \\
\hline Entrepreneurs/merchants & 231.56 & 0.6 & 0.388 \\
Craftsmen & 138.49 & 0.19 & -0.102 \\
Educated bourgeois & 120.56 & 0.18 & 0.006 \\
Employees & 106.25 & 0.12 & -0.06 \\
Vintagers & 61.24 & 0.0 & -0.065 \\
Workers & 48.92 & 0.02 & 0.148 \\
\hline
\end{tabular}

analysis in Table 2 mark the difference between the expected behaviour based on integration into the structure and the actual behaviour. If the number of residuals approaches zero, or is relatively small, this means that observed group behaviour fits the model well.

There were groups, such as the industrial bourgeoisie and merchants, who were the most active during the first stage of mobilization. Out of this group (23 I contacts per person in the first phase) there came many of the leading political figures of the democratic and liberal parties in the town. Esslingen underwent rapid industrial and social change at this time. Already in the Vormärz, new classes, such as entrepreneurs, formed the core of the liberal movement. This group, which had the largest social political and institutional experience, was economically emancipated and called for civil and economic rights. In respect to the overall level of activity and the intensity of contacts in town, this group was followed by the artisans (contact intensity in the first phase: I $_{3} 8$ ) who, with regard to the entire mobilization process, were far more integrated into the social and political life of Esslingen than all other groups. In contrast, the educated bourgeoisie and academics started as a very active group at the beginning of the Revolution, but withdrew as soon as political splits became apparent. At the initial phase of the revolution, workers and vintagers participated only marginally in the petition movement. This changed rapidly in the second phase, when the negotiations in Frankfurt included a large number of different claims and requests, and when the newly written constitution opened up a new process of political bargaining.

During the second phase, the level of participation in the petition movement rose among all social groups, and contact intensity developed into a sort of spiral of mobilization. In this phase, vintagers and workers were the most active participants (activity level: 0.73 and 0.53 ). As the

I0. Tables 2, 3, and 4 are based on the analysis of I,986 individuals for which at least one link is reported to one of the activities, institutions or associations out of which I,284 people have signed at least one of the petitions. 
Table 3. Political behaviour of groups in Phase 2

\begin{tabular}{lccc}
\hline Phase 2 & Intensity & Activity & Residuals \\
\hline Entrepreneurs/merchants & 354.11 & 0.43 & -0.314 \\
Craftsmen & 260.98 & 0.46 & -0.114 \\
Educated bourgeois & 191.3 & 0.23 & -0.388 \\
Employees & 180.56 & 0.25 & -0.33 \\
Vintagers & 162.21 & 0.73 & 0.474 \\
Workers & 162.2 & 0.55 & 0.176 \\
\hline
\end{tabular}

Table 4. Political behaviour of groups in Phase 3

\begin{tabular}{lccc}
\hline Phase 3 & Intensity & Activity & Residuals \\
\hline Entrepreneurs/merchants & 496.28 & 0.9 & -0.058 \\
Craftsmen & 339.5 & 0.86 & 0.113 \\
Educated bourgeois & 271.63 & 0.52 & -0.225 \\
Employees & 244.45 & 0.49 & -0.22 \\
Vintagers & 180.93 & 0.71 & 0.158 \\
Workers & 179.39 & 0.51 & -0.11 \\
\hline
\end{tabular}

remainders show, this activity cannot be accounted for by the degree of integration into the social structure, but was obviously initiated by the political issues. The National Assembly attracted groups that were not, and felt themselves not, represented on the political level before i 848 . The separate professional organization of these groups enhanced this process of self-organization and participation.

The third phase shows a further rise in the number of activities as well as on the level of exposure or contact intensity. Now the integrated and socially established groups of the merchants and industrial bourgeois, and even the academics, returned to the field of action and doubled their activity. The positive residuals indicate that only the vintagers and craftsmen were more active than would be expected in terms of their position in the network of political and social life, but that the educated bourgeoisie and employees were not as highly represented as would be expected, considering their role in the social network. In the third phase, the Esslinger inhabitants signed a mass petition which represented approximately the social strata of the whole city and, moreover, attracted a large number of vintagers and workers. Unlike other German states, the mass petitions of April I 848 in Württemberg were successful. The Württembergian King was one of the few rulers in Germany to accept the Frankfurt Constitution.

Looking at the distribution of professions in the network, it shows a centre with a slight tendency to the right (constitutional and conservative); to the upper right margin, there are the important committees, and welfare 


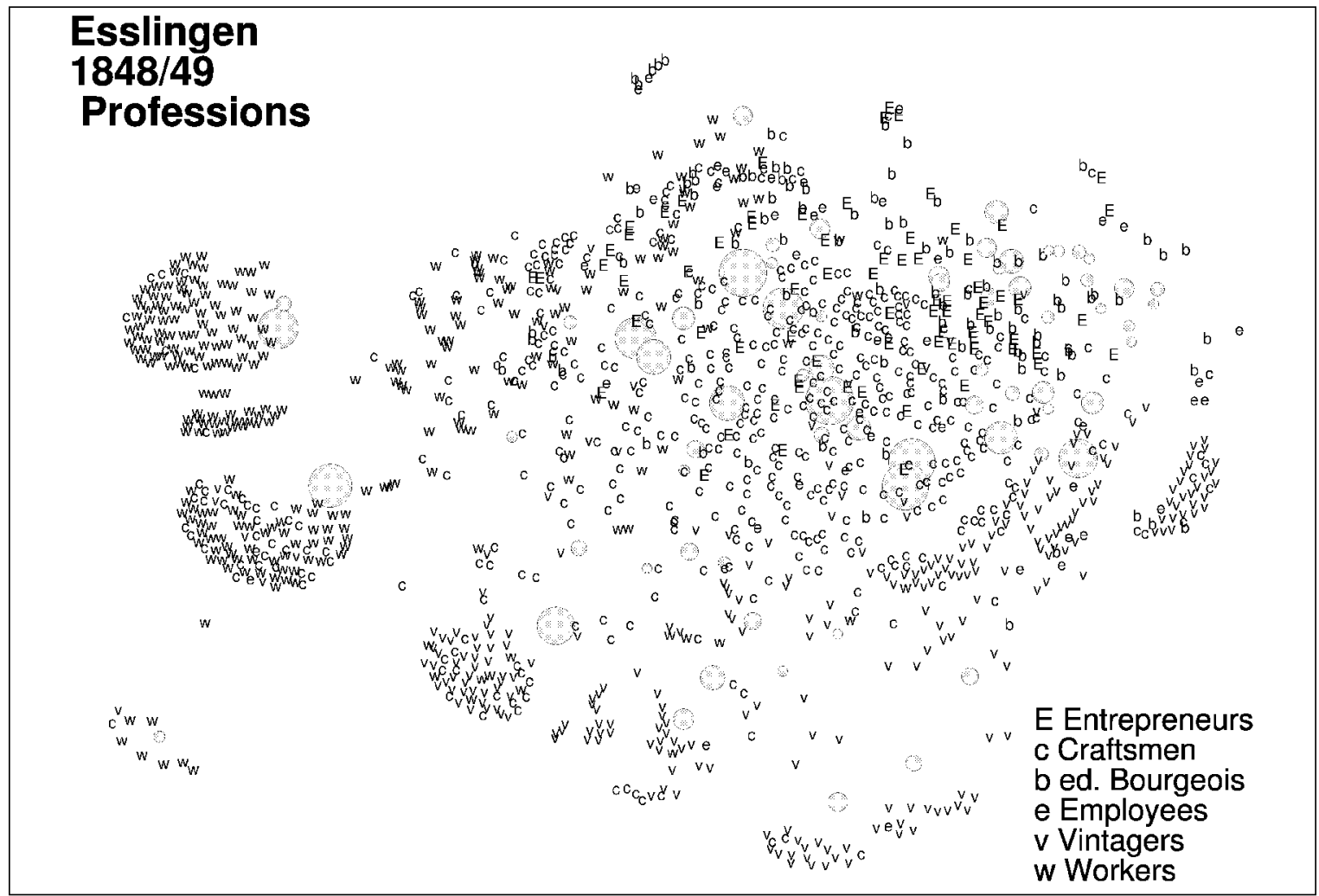


activities. Within these groups the economic groups included the educated bourgeoisie. Their position is reflected in the leading role of these groups in the different organizations founded in pre-Revolutionary and Revolutionary times. In comparison, the workers and vintagers, as newly mobilized groups, were located at the periphery of the network structure. The workers were linked directly to the political factions on the left: radical democrats, and a more or less communist group called the Bruderbund (brotherhood), a sub-organization of the Democratic Party (see the "w" marks in the upper left margin of the network in Figure 8). The vintagers were grouped around the Constitutional Party, which had managed to recruit a great number of the small landowners for their partially conservative claims (see the " $v$ " marks at the right bottom of the graph). Only a small number of vintagers were attracted to the Democratic Party or to substructures that were considered to belong to the democratic camp. What the figure also shows is the dominating position of artisans and craftsmen. This group participated not only because they were embedded in the structure of political life, but also because they really activated the masses; some of the artisans even managed to become speakers for and members of the leading boards of the revolutionary organizations.

The results of this study are twofold. On the one hand, it shows the mechanism of mobilization processes and multiplication of contacts that led to a rapid diffusion of the petition movement and to a spiral of mobilization. On the other hand, we tested a structural model and its deviations that were based on the assumption that a person was more easily mobilized if he had former political experience and, to a certain degree, was integrated into a given social, political and cultural network. The findings show that the impact of social integration into a community and its subcultures in the development of the petition movement during I 848 / I 849 was very strong and explains much of the phenomena. But there were obviously external stimuli that were related to the issues raised by the National Assembly and the process of national unification and liberalization which resulted in a fundamental and overall mobilization during the Revolution. 